\title{
LANDUSE/LANDCOVER CHANGE PROCESS IN A TROPI- CAL SEMI-ARID ZONE: CASE OF TWO RURAL COM- MUNES (CHADAKORI AND SAÉ-SABOUA) IN MARADI REGION, REPUBLIC OF NIGER
}

\section{KADIZA DOULAY ${ }^{1}$, ABDOULAYE DIOUF ${ }^{2 *}$, ABOU-SOUFIANOU SADDA ${ }^{3}$, IBRAHIM BABA YAKUBU ${ }^{4}$}

\author{
${ }^{1}$ Bayero University, Department of Geography, Faculty of Earth and Environmental \\ Sciences, Federal Republic of Nigeria \\ ${ }^{2}$ Dan Dicko Dankoulodo University of Maradi, Department of Soil Sciences and Remote \\ Sensing, Faculty of Agronomy and Environnemental Sciences, Republic of Niger \\ ${ }^{3}$ Dan Dicko Dankoulodo University of Maradi, Department of Soil Sciences and Remote \\ Sensing, Faculty of Agronomy and Environnemental Sciences, Republic of Niger \\ ${ }^{4}$ Bayero University, Department of Environmental Management, Faculty of Earth and \\ Environmental Sciences, Federal Republic of Nigeria \\ *Email: layediouf@yahoo.fr
}

Received 24 August 2019, accepted in revised form 22 November 2019

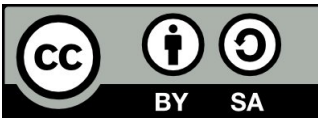

\begin{abstract}
The study aimed to analyze the process of Landuse/Landcover change of two rural communes (Saé Saboua and Chadakori) of Maradi region (Republic of Niger) over the past 28 years (1986 - 2014), through landscape structure analysis by diachronic cartographic approach and landscape indices. Mixed classification of temporal series of Landsat images led to identifying six Landuse/Landcover (LULC) classes, namely "cultivated land under shrubs and trees", "cultivated land under trees", "continuous cropland", "fallow/pasture land", "forest reserve", and "settlement". The composition and structure of the studied landscapes have greatly changed from 1986 to 2014. The class "cultivated land under trees" was the landscape matrix in 1986 with $38.65 \%$ of landscape total area but in 2001 and 2014 the class "continuous cropland" became the landscape matrix. The changes also affected the "forest reserve" which was transformed to smallholder agricultural land from 1986 to 2014. The area occupied by classes "cultivated land under trees" changed from 38.65\% in 1986 to 8.78\% in 2014; and from 1986 to 2014 , the area occupied by "fallow/pasture land" has decreased of about $16 \%$. The decrease in these classes was in favor of "continuous crop land", "settlement" and "cultivated land under shrubs and trees" which respectively gained $38 \%, 0.3 \%$ and $8.15 \%$ of their areas in 1986 . The results of this study reflect the problem of access to land and even land saturation in semi-arid region, a consequence of strong population growth. They also contribute to a better rethinking of agricultural practices in order to initiate adaptation and resilience strategies for the population facing food insecurity and poverty.
\end{abstract}

Keywords: Landuse/Landcover, Landscape structure, GIS/Remote Sensing, Landscape change, Anthropization, Land management, Sahel, Niger Republic 


\section{Introduction}

In recent years, global climate change and human activity have no doubt affected physical and biological systems (Marthews et al., 2019), particularly in the semi-arid regions experiencing rising temperatures, frequent drought events and changes in precipitation regimes since the 1970s (John et al., 2009; Mertz et al., 2011; Sarr, 2012). According to IFAD and UNEP (2013), seventy percent of the 1.4 billion people are living on less than US $\$ 1.25$ a day live in rural areas where agriculture is a major livelihood activity and where the majority only has access to small ( $<2 \mathrm{ha}$ ) areas of agricultural land (World Bank, 2007). In Niger, $81 \%$ of the population lives in rural areas with land becoming increasingly insufficient because of the high rate of population growth $(3.7 \%)$ leading to increased natural resource consumption (World Bank, 2015). With a view to increasing food security and reducing poverty, smallholders are pushed to expand their farm holdings, leading to exacerbated natural resource degradation (forest, soil, water) (Lawali and Yamba, 2012). This degradation is manifested through a reduction in biodiversity and plant cover (Mahamane et al., 2007), and soil erosion (Sultan and Janicot, 2004). Other ecological consequences include, loss of key species, with others becoming endangered and threatened (Currit and Easterling, 2009), and land fragmentation (Fuller, 2001). Furthermore, the management of natural resources has become more constrained and complex due to the several levels of interactions among ecological, political, socioeconomic, demographic and behavioral factors (Kim and Ellis, 2009). To better understand how humans and climate factors are influencing LULC changes, remote sensing and geographic information system (GIS) are now being applied widely because of its quick analysis and near accurate results and ability to present visual and spatial information (Zang, 2003; Diouf et al., 2012). This study is aimed at providing landscape change information to resource managers and decision makers and is also about understanding the relations between landscape spatial structure and anthropogenic factors in a part of semi-arid zone of Niger.

\section{Materials and methods}

\section{Study site}

The study was conducted in Chadakori and Saé Saboua, two rural communes of Maradi region, located between latitudes $13^{\circ} 5^{\prime} 97^{\prime \prime}$ and $13^{\circ} 9^{\prime} 14^{\prime \prime}$ North and longitudes $7^{\circ} 6^{\prime} 03^{\prime \prime}$ and $7^{\circ} 49^{\prime} 02^{\prime \prime}$ East in south central Niger Republic (Figure 1). It occupies an estimated area of $2,566 \mathrm{~km}^{2}$. It experiences a semi-arid climate characterized by a short rainy season that is followed by eight months of dry season (Sadda et al., 2016). The mean annual precipitation over the past 30 years is about $469.4 \mathrm{~mm}$. The mean annual temperature is $28 \mathrm{oC}$ with a relative humidity averaging 56\% (DNM, 2015). The hydrological network in the area consists essentially of temporal ponds which do not last to allow the development of irrigated crops.

The soil is principally sandy and loamy sandy, and is less fertile, even though it supports some woody vegetation dominated by Piliostigma reticulatum Hochst, Ziziphus mauritiana L., Guiera senegalensis J.F. Gmel, Combretum nigricans Lepr., Combretum glutinosum Pierr., Combretum micranthum G.Don., Faidherbia albida A.Chev., and Commiphora africana Engl.

The human population of the study area was estimated at 208,349 inhabitants in 2012, with $51.8 \%$ being women, compared with only 135,700 inhabitants in 2001, corresponding to an average annual growth rate of $3.97 \%$, slightly higher than national rate $(3.7 \%)$ (INS, 2014). Scarcity of natural resources, continued decline in agricultural productivity, followed by rampant food crisis, decline in purchasing power of households caused by the adverse impact of climate 


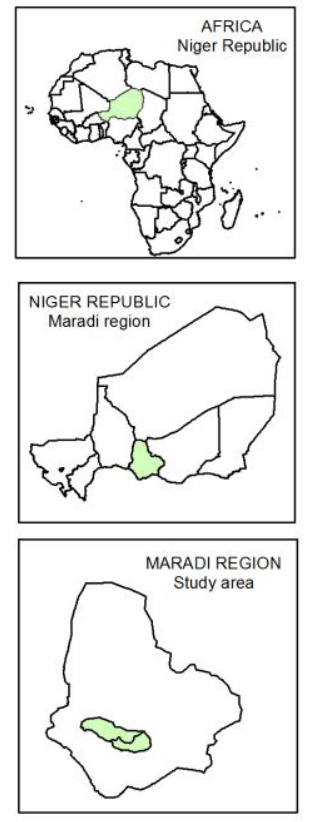

Realization: Kadiza Doulay Seydou, July 2019

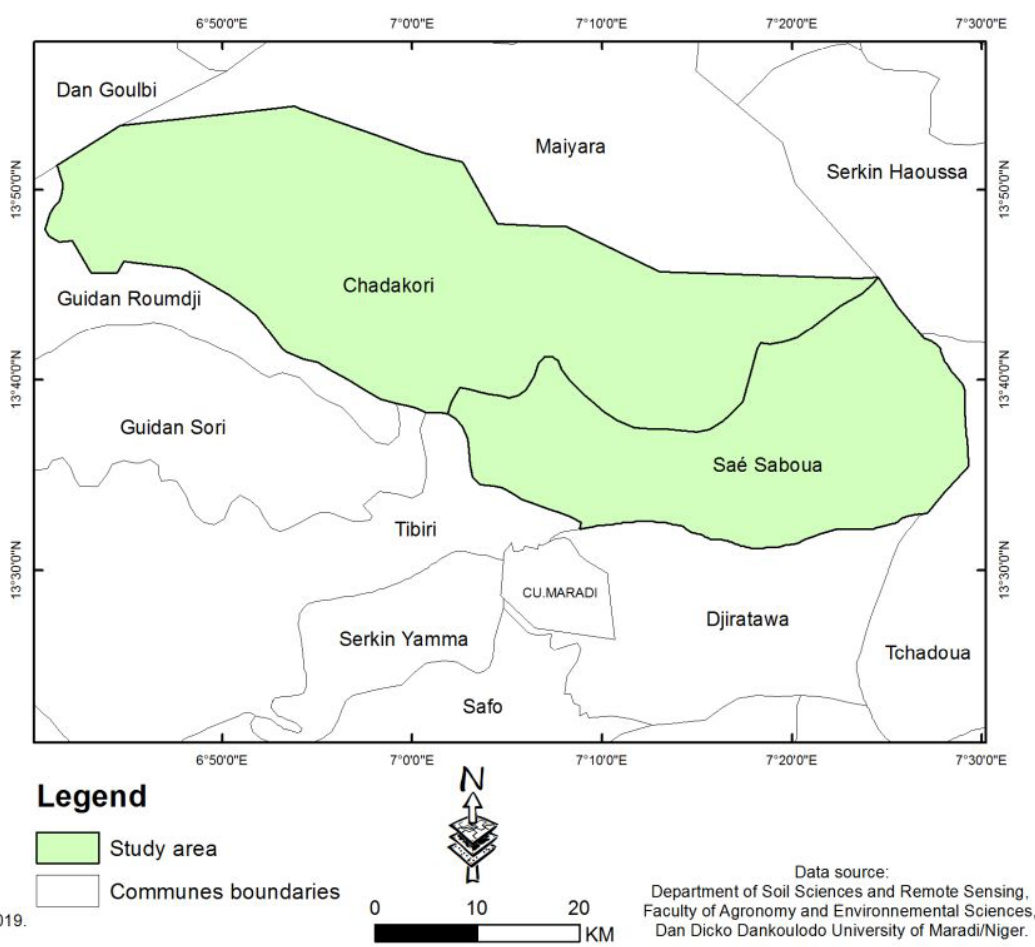

Fig. 1. Geographic localization of Saé-saboua and Chadakori communes in Maradi Region

(Republic of Niger)

change have all combined to increase the vulnerability of people, who are often pushed to migrate from rural to urban centers (Lawali and Yamba, 2012).

\section{Satellite data acquisition and pre-pro- cessing}

To analyze 28 year LULC changes, three Landsat satellite images from different sensors, different spatial resolutions, different tiles and different dates (1986 MSS: Multispectral Scanner; 2001 - ETM+: Enhance Thematic Mapper Plus; and 2014 OLI/TIRS: Operational Land Imager/Thermal Infrared Sensor) (Table 1), were acquired through the tool Earth Explorer from United States Geological Survey (USGS) official website (http://earthexplorer.usgs.gov/ on $15 / 07 / 2015)$. The choice of the sensors is based on their resolutions according to the study objectives; and the availability of the

Table 1. Details of acquired Landsat images

\begin{tabular}{|c|c|c|c|c|c|}
\hline Satellite ID & $\begin{array}{l}\text { Sensor } \\
\text { ID }\end{array}$ & $\begin{array}{l}\text { Path/ } \\
\text { Row }\end{array}$ & $\begin{array}{l}\text { Acquisition } \\
\text { date }\end{array}$ & $\begin{array}{l}\text { Spatial } \\
\text { resolution }\end{array}$ & Band \\
\hline \multirow{3}{*}{ Landsat 3} & \multirow{3}{*}{ MSS } & $189 / 051$ & $14 / 10 / 1986$ & \multirow{3}{*}{$60 \mathrm{~m}$} & Band $1(0.50-0.60)$ \\
\hline & & & & & Band $2(0.60-0.70)$ \\
\hline & & $190 / 050$ & 23/10/1986 & & Band $3(0.70-80)$ \\
\hline \multirow[b]{2}{*}{ Landsat 7} & \multirow[b]{2}{*}{ ETM+ } & $189 / 051$ & $22 / 09 / 2001$ & \multirow[b]{2}{*}{$30 \mathrm{~m}$} & Band $2(0.52-0.60)$ \\
\hline & & $190 / 050$ & & & $\begin{array}{c}\text { Band } 3(0.63-0.69) \\
\text { Band } 4(0.76-90)\end{array}$ \\
\hline \multirow{2}{*}{ Landsat 8} & \multirow{2}{*}{$\begin{array}{l}\text { OLI/ } \\
\text { TIRS }\end{array}$} & $189 / 051$ & $21 / 11 / 2014$ & \multirow{2}{*}{$30 \mathrm{~m}$} & Band 3 (0.53-0.59) \\
\hline & & $190 / 050$ & $28 / 11 / 2014$ & & $\begin{array}{c}\text { Band } 4(0.63-0.67) \\
\text { Band } 5(0.85-87)\end{array}$ \\
\hline
\end{tabular}


images. Two scenes (Path 189 Row 051 and Path 190 Row 050 according to the World Reference System WRS2) necessary to cover the entire study zone were taken during the dry season when the biomass reflectance values are lowest for the achievement of the goal of this study.

Image radiometric correction and atmospheric calibration were done by their provider. An operation of mosaicking of the two scenes of the closest date was done to obtain a single image. Specially, the image of 1986 was resampled using the nearest neighbor algorithm to harmonize the images spatial resolution (from $80 \mathrm{~m}$ to $30 \mathrm{~m}$ resolution for the MSS sensor image) (Schowengerdt, 2007).

Additional pre-processing operations were done under the software ENVI $4.5 \AA$ in order to correct and/or improve images geometrically and radiometrically. So, the operations of visual improvement as smoothing, contrast linear adjustment at $2 \%$, and image editing (false color composite) to better differentiate vegetation classes (Diouf et al., 2012). These operations facilitated their reading, visual interpretation on the screen, and preparation for the ground controls.

\section{Image classification and accuracy assess- ment}

Mixed classification approach was applied on the three multispectral images for an analytical and/or selective extraction of needed information. At first, the visual interpretation of these images according to color, texture, structure, and shape of image objects was done to determine the number of main LULC classes. Then an unsupervised classification using the Isodata algorithm which groups the pixels of each image in objective LULC classes, based on its reflectance values.

To improve the classification and determine the land use classes, ground truthing points were identified in each of the established LULC classes. The gathered information was then used to establish the training sites corresponding to objects recognized as representative of a class on the pre-processed image. The supervised signature extraction with the maximum likelihood algorithm was employed to perform the classification of the satellite images. It used statistical training sites to calculate the probability of membership of each pixel to one of the classes (Bonn and Rochon, 1992).

Post-classification operations such as the application of a majority Kernel filter (3x3 pixels window) to reduce the "salt and pepper" effect on the classified image (Abdourahamane et al., 2015), and the combination of some very close classes in connection with land use was applied. In order to validate the classification of the different images, a confusion matrix was used to assess the quality of the classification with the Kappa coefficient (K) and statistics on errors of commission and omission (Story and Congalton, 1986; Sadda et al., 2016).

\section{Statistical analysis of landscape change}

GIS operations (ArcGIS 10.2 (C) such as vectorization of classified images, extraction, and layout of the portion corresponding to the limits of the study area were used to develop LULC maps corresponding to the three selected dates (1986, 2001 and 2014). So, to characterize Chadakori and Saé Saboua communes' landscape structure, three (3) landscape composition metrics were calculated by using Fragstats 4 software. These are:

- Number of patches (NP) is a simple measurement of the landscape composition determines the degree of heterogeneity or fragmentation of that landscape.

$$
N P=n_{i}
$$

$n i=$ number of patches in the class type $\mathrm{i}$. The more the number of patches, the more fragmented the class is (McGarigal, 2015).

- Class area (CA) is a measure of landscape composition; specifically, how 
much of the landscape is comprised of a particular class type. It was calculated as follows:

$$
C A=\sum_{j}^{n} \operatorname{aij}\left(\frac{1}{10,000}\right)
$$

$a_{i j}=$ area $\left(\mathrm{m}^{2}\right)$ of a patch $j$ in the class $i$.

- PLAND, is a measure of landscape composition and is calculated as follows:

$$
\text { PLAND (\%) }=P_{i}=\frac{\sum_{j=1}^{n} a_{i j}}{A}
$$

$P L A N D=P i=$ proportion of the landscape occupied by LULC class type $i(0<$ PLAND $\leq$ 100); n=number of patches; $a_{i j}=$ area of patch $j$ in class $i\left(\mathrm{~m}^{2}\right)$; and $A$ =total landscape area $\left(\mathrm{m}^{2}\right)$.

LULC change detection was performed through transition matrix, a cross-tabulation which describes the change status among LULC classes from a time $\mathrm{T}_{0}$ to $\mathrm{T}_{1}$ (Schlaepfer, 2002). The transformations in a given class are either against or in favor of another. On the diagonal are the proportions of classes that remained stable during the considered period. The resulting tabulations displayed quantitative data for the overall LULC change (from 1986 to 2014) and the intermediary

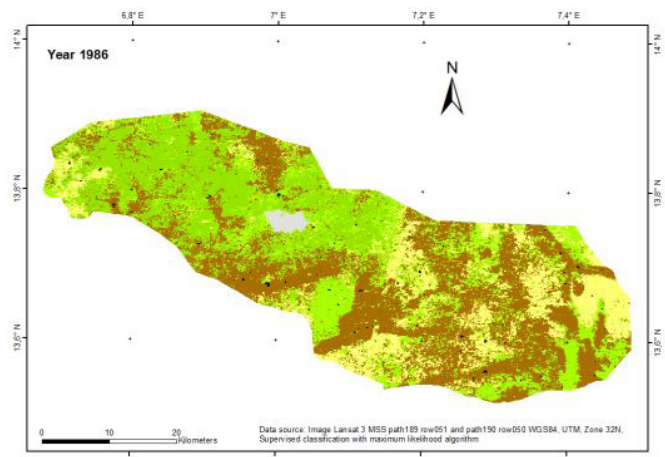

changes (from 1986 to 2001; and from 2001 to 2014).

\section{Results}

\section{Landuse/landcover mapping}

Six (6) LULC classes were identified through mixed classification (Figure 2). These are "cultivated land under shrubs and trees", "cultivated land under trees", "continuous cropland", "fallow/pasture land", "settlement", and "forest reserve". The proportions of classes varied between the considered years (Figure 3). The overall accuracy and Kappa index (Table 2) indicates a very good to an excellent classification according to Landis and Koch (1977).

\section{Spatio temporal analysis of LULC Change from 1986 to 2014}

The spatiotemporal analysis of LULC in 1986 reveals "cultivated land under trees" at $38.65 \%$ of the landscape total area to being the landscape matrix (Figure 3), while the class "forest reserve" at $0.81 \%$ has the smallest proportion in the landscape. From

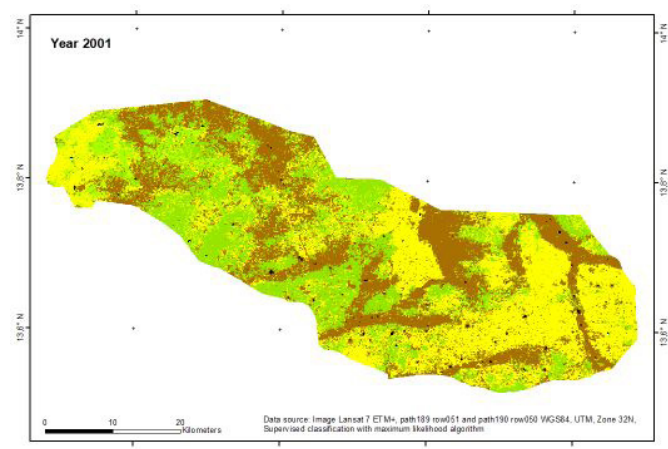

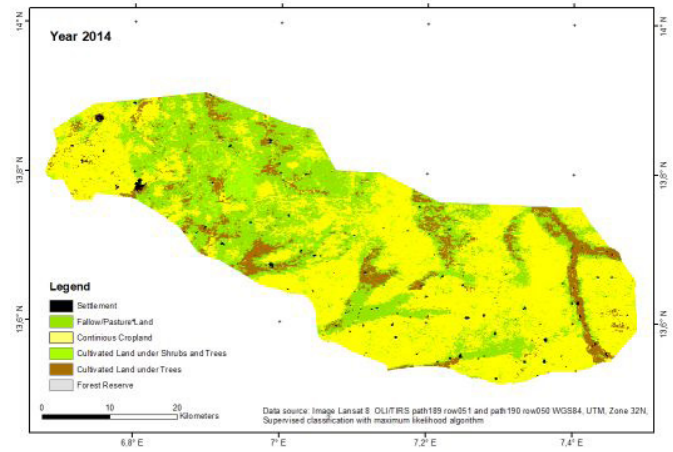

Fig. 2. Chadakori and Saé-saboua landscapes changes from 1986 to 2014 


\begin{tabular}{cccc}
\multicolumn{4}{c}{ Table 2. Images classification accuracy } \\
\hline & 1986 & 2001 & 2014 \\
\hline Kappa index (\%) & 90.49 & 91.53 & 91.43 \\
Overall accuracy (\%) & 89.43 & 93.41 & 93.18 \\
\hline
\end{tabular}

1986 to 2001 (intermediate period $\mathrm{T}_{1}$ ) "cultivated land under trees" and "fallow/ pasture land" classes have decreased to the gain of "continuous cropland" class mainly (Table 3) which became the landscape matrix (36.17\% of the total area). A slight increase was observed in "cultivated land under shrubs and trees" class whereas the class "forest reserve" has completely disappeared in the landscape (Figure 3). In the intermediate period T2 (2001 - 2014) the same tendency of reduction was observed in all the LULC classes except "continuous cropland" class representing the landscape matrix at 2014 (53.33\%), "settlement" class $(0.63 \%)$ and "cultivated land under shrubs and trees" class which increased by about 7\% (Figure 3).

The transition matrix (Table 3) reveals that change of LULC class area, from 1986 to 2014 , is characterized by regressive and/or progressive trends according to the classes and considered intermediate periods (1986-2001; 2001-2014). Indeed, "cultivated land under trees", "forest reserve" and "fallow/pasture land" classes' area present a continuous regressive trend, with

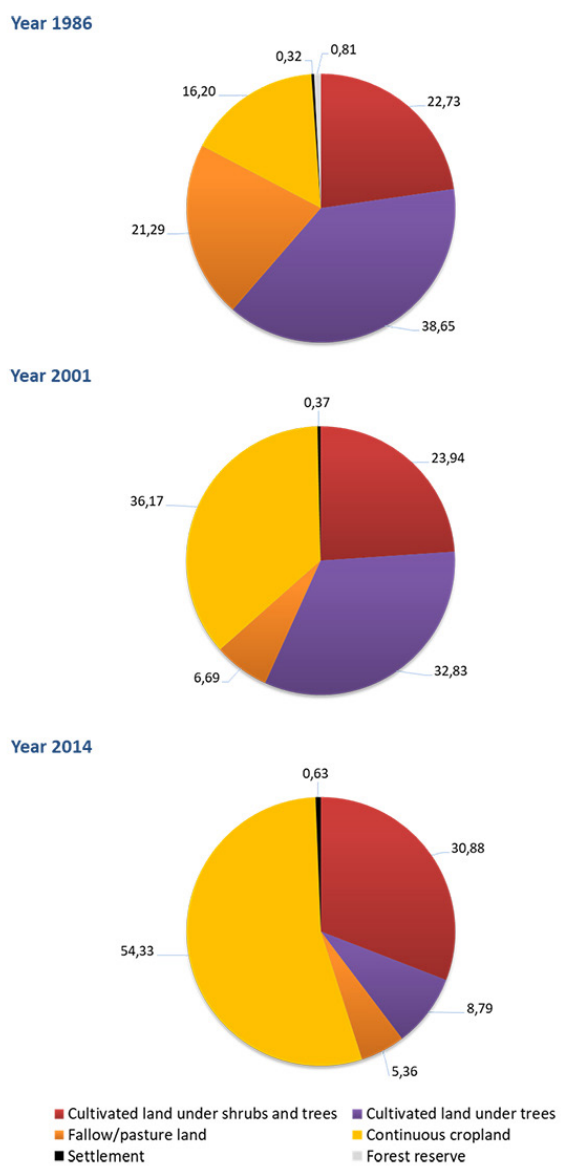

Fig. 3. Variations of Landuse/Landcover (LULC) classes' area proportion from 1986 to 2014 
Table 3. Transition matrix from 1986 to 2014 (STL= Settlement, CCL= Continuous cropland, CLST= Cultivated land under shrubs and trees, F/PL= fallow/pasture land, CLT=Cultivated land under trees,

FR= Forest Reserve)

\begin{tabular}{|c|c|c|c|c|c|c|c|c|}
\hline \multicolumn{9}{|l|}{1986} \\
\hline CCL & & 14.01 & 1.57 & 0.00 & 0.60 & 0.02 & 0.00 & 16.20 \\
\hline CLST & & 20.13 & 0.34 & 0.00 & 0.27 & 2.01 & 0.00 & 22.75 \\
\hline STL & & 0.00 & 0.00 & 0.31 & 0.00 & 0.01 & 0.00 & 0.32 \\
\hline $\mathrm{F} / \mathrm{PL}$ & & 1.61 & 8.92 & 0.01 & 5.68 & 5.05 & 0.00 & 21.27 \\
\hline CLT & & 0.32 & 13.01 & 0.05 & 0.1 & 25.17 & 0.00 & 38.61 \\
\hline $\mathrm{PF}$ & & 0.1 & 0.1 & 0.00 & 0.04 & 0.57 & 0.00 & 0.81 \\
\hline Total & & 36.17 & 23.94 & 0.37 & 6.69 & 32.83 & 0.00 & 100 \\
\hline \multicolumn{9}{|c|}{2014} \\
\hline \multicolumn{9}{|l|}{2001} \\
\hline CCL & & 31.12 & 0.90 & 0.00 & 4.15 & 0.00 & 0.00 & 36.17 \\
\hline CLST & & 18.03 & 5.70 & 0.01 & 0.01 & 0.19 & 0.00 & 23.94 \\
\hline STL & & 0.00 & 0.00 & 0.36 & 0.00 & 0.01 & 0.00 & 0.37 \\
\hline $\mathrm{F} / \mathrm{PL}$ & & 5.02 & 0.22 & 0.25 & 1.20 & 0.00 & 0.00 & 6.69 \\
\hline CLT & & 1.35 & 24.06 & 0.00 & 0.00 & 7.42 & 0.00 & 32.83 \\
\hline Total & & 55.33 & 30.88 & 0.63 & 5.36 & 8.78 & 0.00 & 100 \\
\hline \multicolumn{9}{|c|}{2014} \\
\hline \multicolumn{9}{|l|}{1986} \\
\hline CCL & & 10.70 & 5.08 & 0.00 & 0.42 & 0.00 & 0.00 & 16.20 \\
\hline CLST & & 19.03 & 0.10 & 0.01 & 0.60 & 3.01 & 0.00 & 22.75 \\
\hline STL & & 0.00 & 0.11 & 0.12 & 0.08 & 0.01 & 0.00 & 0.32 \\
\hline $\mathrm{F} / \mathrm{PL}$ & & 0.03 & 11.86 & 0.00 & 4.08 & 5.32 & 0.00 & 21.29 \\
\hline CLT & & 24.08 & 13.52 & 0.50 & 0.08 & 0.43 & 0.00 & 38.61 \\
\hline $\mathrm{PF}$ & & 0.49 & 0.21 & 0.00 & 0.10 & 0.01 & 0.00 & 0.81 \\
\hline Total & & 54.33 & 30.88 & 0.63 & 5.36 & 8.78 & 0.00 & 100 \\
\hline
\end{tabular}

a degree of regression for class "cultivated land under trees" higher during $\mathrm{T}_{2}$ than $\mathrm{T}_{1}$, while it is more important in $\mathrm{T}_{1}$ than $\mathrm{T}_{2}$ for class "fallow/pasture land" (Table 3). As for the class "forest reserve", it has completely disappeared from the landscape in favor of classes related to crops. This loss of class area was mainly in favor of the "continuous cropland" and "cultivated land under shrubs and trees" classes. A continuous progressive trend during all the intermediate periods $\left(\mathrm{T}_{1}\right.$ and $\mathrm{T}_{2}$ ) was observed in "continuous cropland", "cultivated land under shrubs and trees" and "settlement" classes to the detriment of the "fallow/pasture land" and "cultivated land under trees" classes in particular.

In each class some area proportion stay unchanged in terms of land use, from one intermediate period to another. These stable areas present increased proportions during the intermediate periods for "continuous cropland" and "cultivated land under shrubs and trees" classes, whereas they decreased significantly in "cultivated land under trees" and "fallow/pasture land" classes (Table 3). 


\section{Process of landscape change}

To determine the landscape changeinduced processes from 1986 to 2014, the decision tree proposed by Bogaert et al. (2004) was used. So, five major landscape transformations processes took place in the studied landscape. These transformations vary among classes and they differ from period to period. During the past 28 years (from 1986 to 2014), patches aggregation $\left(\mathrm{n}_{2001}<\mathrm{n}_{1986}\right.$ and $\left.\mathrm{a}_{2001}>\mathrm{a}_{1986}\right)$ in $\mathrm{T}_{1}$ and patches creation $\left(\mathrm{n}_{2014}>\mathrm{n}_{2001}\right.$ and $\left.\mathrm{a}_{2014}>\mathrm{a}_{2001}\right)$ in $\mathrm{T}_{2}$ are the main change processes in "cultivated land under shrubs and trees" class (Figure 4A). Likewise, there was a patches suppression in cultivated land under trees class aches in the landscape throughout the 28 years $\left(\mathrm{n}_{2001}<\mathrm{n}_{1986}\right.$ and $\mathrm{a}_{2001}<\mathrm{a}_{1986} ; \mathrm{n}_{2014}<\mathrm{n}_{2001}$ and $\mathrm{a}_{2014}<\mathrm{a}_{2001}$ ) (Figures 4B). The main processes influencing changes in "continuous cropland" class are patches creation $\left(\mathrm{a}_{2001}>\mathrm{a}_{1986}\right.$ and $\mathrm{a}_{2014}>\mathrm{a}_{2001}$ ) during $\mathrm{T}_{1}$ and patches aggregation $\left(\mathrm{n}_{2014}<\mathrm{n}_{2001}\right.$ and $\left.\mathrm{a}_{2014}>\mathrm{a}_{2001}\right)$ during $\mathrm{T}_{2}$ (Figure 4C). In "settlement" class, there was a creation of patches all through the period $\mathrm{T}$ and the existing patches increased in size $\left(\mathrm{a}_{1986}<\mathrm{a}_{2001}<\mathrm{a}_{2014}\right)$ (Figure 4D). Patches fragmentation process which dominated "fallow/pasture land" class during the $\mathrm{T}_{1}$, is replaced by patches suppression process during $\mathrm{T}_{2}$ (Figure $4 \mathrm{E}$ ).

\section{Discussion}
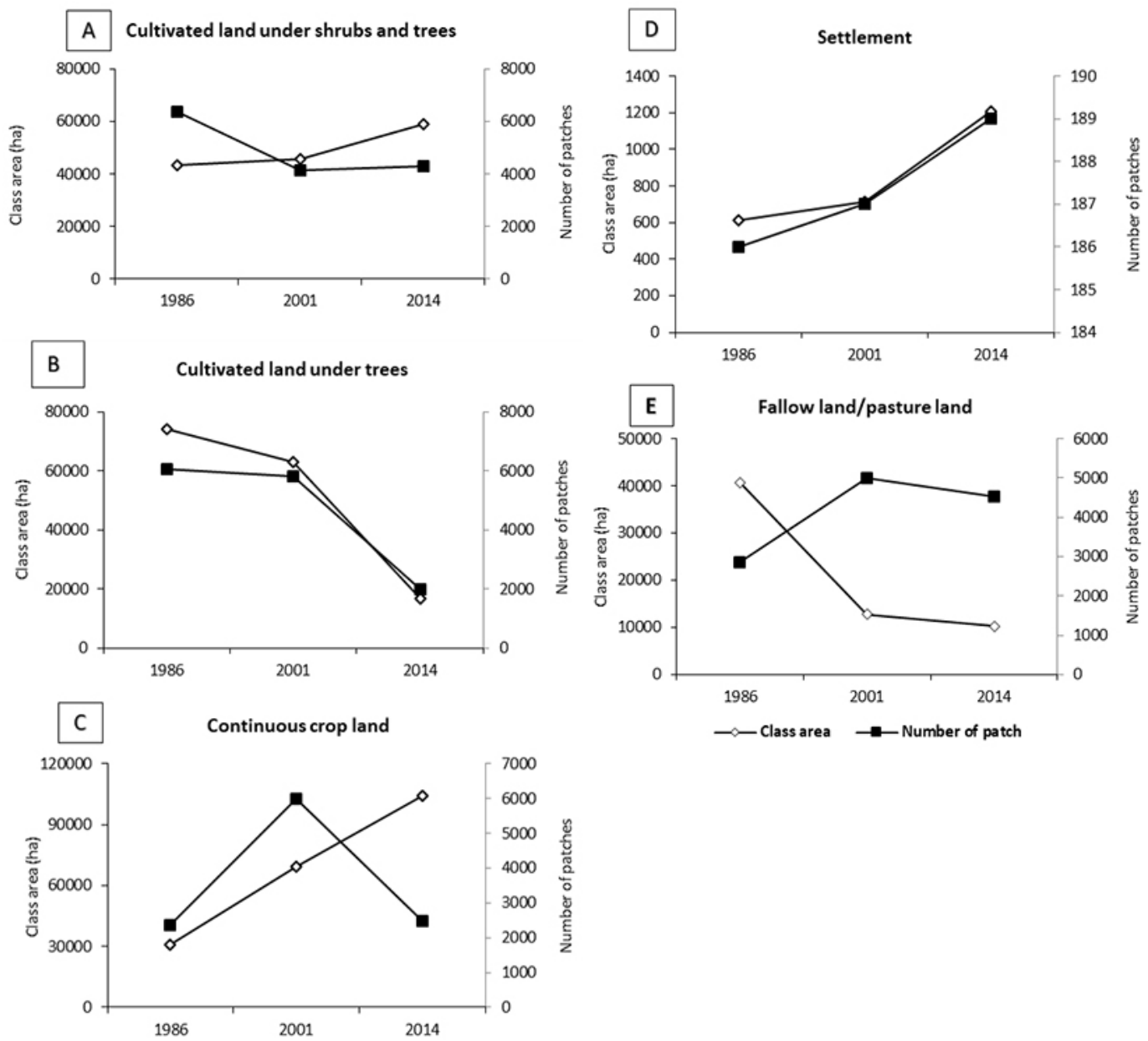

Fig. 4. Change of number of patches and class area from 1986 to 2014 
The Kappa values above 90\% obtained during the study showed that the mixed classification method is reliable and statistically acceptable (Landis and Koch, 1977). The lower resolution of the Landsat MSS sensor relative to that of ETM+ and OLI/TIRS sensors impacted on kappa and overall accuracy values recorded for the 1986 map. This is a challenge faced in the classification of MSS sensor due to their low spatial resolution (Barima, 2007; Leroux, 2012; Abdourahamane et al., 2015). It is also important to note that the three data is quiet few to evaluate the process of 28 years. However it allows to see a broad view of the change.

One of the key striking changes in the landscape from 1986 to 2014 is the suppression of the "forest reserve" class. The conversion of this forest, the so-called Kourounkoussa, to agricultural land was as the result of policy change. The conversion of "cultivated land under trees" to "cultivated land under shrubs and trees" can be explained by the cutting down of trees by farmers to use as fuel, to clear the farms and by pastoralist herders to feed their animals. Because most of the trees in the area have good potential to regenerate, after some time new shoots start to germinate and grow to shrubs. Likewise, the conversion of Kourounkoussa forest reserve to agricultural land was as a result of policy change. That forest was preserved since 1953 with an initial area of 2,300 hectares but due to the increase in population size and an insufficiency of land, it became devastated. The population began hunting from the forest to cultivate their crops because of the reduction in their crop production amplified by the drought of 1970-1980s (Lawali and Yamba, 2012). This has caused a great reduction in the forest area. In 1986 only 1560 hectares remained. The government saw the need for land was becoming higher, compelling them to change policy. The forest was therefore allocated to farmers.

The conversion of "continuous cropland" towards "cultivated land under shrubs" was also observed by Ibrahim (2007), Abdou (2007), Boubé (2008) in Maradi region. This could be explained by the implementation of the policy of Assisted Natural Regeneration (ANR) since 1983 (Rinaudo, 2010) by the national authorities as a new strategy with a view to reversing the effect of drought in the second part of 20th century and anthropogenic actions (Hountondji, 2008; Ibro and Assoumane, 2009).

Consequently, the practice of Assisted Natural Regeneration (ANR) was developed through the support of several development projects including PDRM (Rural Development Project in Maradi) and PASADEM (Project for Food Security Support and Development in Maradi Region). However, in Saé-saboua and Chadakori communes, the practice of ANR is not fully developed, compared to other areas in Niger republic (Ibrahim, 2007).

The decrease in the class "cultivated land under trees" could be as the result of the cutting down of trees by the population for energy use and for the cultivation of some crops like tiger nuts which couldn't produce well under shadow. The extension of settlement may be explained by the increase in the population rate in Chadakori and Saé Saboua.

The decision tree proposed by Bogaert et al., (2004) and used in this study to identify transformation processes presents certainly many advantages, but it causes some significant questions all the same. Indeed, this tree uses the area, the perimeter and the number of patches as input data. The satellite images are raster data and the smallest element is represented by a pixel of square form. This smaller element is thus represented by a surface of $900 \mathrm{~m}^{2}$. But for another type of image (Spot for example), the smallest surface will be different from $900 \mathrm{~m} 2$. It should be noted also that this decision tree does not take into account certain parameters of space, such as the average size of the patch, the interior of the patch and the connectivity of the patch (Barima, 2007). But the fact that these characteristics are directly 
related to the process of fragmentation and that they are also less significant for the other processes of landscape change could explain the fact that these parameters are not be taken into account (Barima et al., 2009). Finally, another limit of this decision tree is the subjectivity of the value of $t$ which makes it possible to make the distinction between the dissection and fragmentation. Indeed, no indication is given on this value. tobs can thus take values according to appreciations of the operator (Sadda et al., 2016).

\section{Conclusion}

Remote sensing and landscape metrics are good and reliable tools for understanding the spatial and temporal changes of semiarid landscape. This study allowed us to characterize the spatiotemporal dynamics of the landscape of Chadakori and Saé Saboua which revealed it to be dynamic over the study period. These changes were in part as the result of human activities. Throughout their history, human societies have coevolved with their environment through change, instability, and mutual adaptation. The coupled human-environment systems should, therefore, be considered as a whole when we assess sustainability and vulnerability. The findings of this study represent a valuable tool for natural resource managers, in that it may be the basis for understanding the dynamics of Chadakori and Saé Saboua for a sound decision-making process.

\section{Acknowledgement}

This research was financially supported by the Center for Dryland Agriculture (Africa Center of Excellence) of Bayero University, Kano (Nigeria Federal Republic) and the partnership with Faculty of Agronomy and Environmental Sciences of Dan Dicko Dankoulodo University of Maradi (Niger Republic).

\section{References}

Abdou, F. (2007): Impact de la RNA sur la fertilité du sol : cas du terroir de Guidan Bakoye (Aguié). \{Impact of ANR on soil fertility: case of Guidan Bokoye (Aguié)\} Mémoire de fin d'études d'ingénieur de technique agricole (ITA), Faculté d’Agronomie, Université Abdou Moumouni de Niamey/Niger, 38 p.

Abdourahamane, I. S. - Diouf, A. -Moussa, M. B. Sadda, A. S. -Mahamane, A. - Mahamane, S. (2015): Dynamics of a third world city: Case of Niamey, Niger. Journal of Geography and Regional Planning 8: 120-130., DOI: 10.5897/ JGRP2015.0491

Barima, Y. S. (2007): Dynamique du paysage d'une zone de transition forêt-savane dans le département de Tanda à l'Est de la côte d'Ivoire. \{Landscape dynamic in a forest savana transition area in Tanda in the eastern Ivory Coast\} Mémoire DEA, Faculté des Sciences, Service de Botanique Systématique et Phytosociologie, Laboratoire d'Ecologie du Paysage, Université de Bruxelles, Belgique, 65 p.

Barima, Y.S.S. - Barbier N. - Bamba I. - Traoré D. - Lejoly J- Bogaert J. (2009): Dynamique paysagère en milieu de transition forêts savane ivoirienne. \{Landscape dynamics in in a forest savana transition area of Ivory Coast \} Bois et Forêts des tropiques 299 (1): 15-25. DOI: $10.19182 / \mathrm{bft} 2009.299 . a 20419$

Boubé, R. (2008) : Impact de la régénération naturelle assistée sur la production agricole dans le département d'Aguié : cas du terroir villageois de Guidan Bakoye. \{Impact of assisted natural regeneration on the agricultural production in Aguié district: case of Guidan Bakoye village\}. Rapport de stage, Université Abdou Moumouni de Niamey, Niger, 41 p.

Bogaert, J. -Ceulemans, R. - Salvador-Van Eysenrode, D. (2004): Decision Tree Algorithm for Detection of Spatial Processes in Landscape Transformation. Environmental Management 33(1): 62-73., DOI: 10.1007/s00267-0030027-0

Bonn, F.J. - Rochon, G. (1992): Précis de télédétection. Volume 1, Principes et méthodes. \{Precision of remote Sensing, vol I principles and methods\}, Presses de l'Université du Québec/ AUPELF, Sainte-Foy et Montréal (Québec), 485 p.

Currit, N. - Easterling, W.E. (2009): Globalization and population drivers of rural-urban landuse change in Chihuahua, Mexico. Land Use Policy 26 (3): 535-544., DOI: 10.1016/j. landusepol.2008.08.001 
Diouf, A. - Barbier, N. - Lykke, A.M. -Couteron, P. -Deblauwe, V. - Mahamane, A. - Saadou, M. Bogaert, J. (2012): Relationships between fire history, edaphic factors and woody vegetation structure and composition in a semi-arid savanna landscape (Niger, West Africa). Applied Vegetation Science 15: 488-500. DOI: 10.1111/j.1654-109X.2012.01187.x

Direction Nationale de la Météorologie (2015): Données météorologique de la région de Maradi, République du Niger. \{Meteorological data of Maradi region, Niger Republic\}

Fuller, D.O. (2001): Forest fragmentation in Loudoun County, Virginia, USA evaluated with multitemporal Landsat imagery. Landscape Ecology 16: 627-642., DOI: https://doi. org/10.1023/A:1013140101134

Hountondji, Y. H. (2008): Dynamique environnementale en zones sahélienne et soudanienne de l'Afrique del'Ouest: Analyse des modifications et évaluation de la dégradation du couvert végétal. \{Environmental dynamic in sahelian and sudanian areas of West Africa: modifications analysis and evaluation of vegetation cover degradation\}. Bruxelles, Université Libre de Bruxelles, thèse de doctorat en Science et Gestion de l'Environnement, 131 p.

John, R. - Chen, J. - Lu, N. - Wilske, B. (2009): Land cover/land use change in semi-arid Inner Mongolia: 1992-2004. Environmental Research Letter 4: 045010., DOI: 10.1088/1748-9326/4/4/045010

Ibrahim H. (2007): Impact de la régénération naturelle assisté des lignées sur la réduction de la vulnérabilité des ménages dans le département d'Aguié : cas des villages de Dan Damou, Guidan Bakoye, Guidan Adamou. Assisted natural regeneration impact on householder's vulnerability reduction in Aguié district: Dan Damou, Guidan Bakoye and Guidan Adamou\}. Université Abdou Moumouni Niamey, Niger (UAM), mémoire de DEA en Géographie, option Aménagement: Aménagement et Gestion des Espaces Ruraux, $70 \mathrm{p}$.

Ibro, A. - Assoumane, G. (2009): Etudes de cas sur l'évaluation de la dégradation des forêts : occupation des sols des forêts classées du Niger et l'analyse des dynamiques de changement \{A Case study of the evaluation of forests degradation: Landuse of preserved forests in Niger and analysis of change dynamics\}. 25 p.

IFAD, UNEP (2013): Small holders, food security, and the environment. 44- 00142 Rome, Italy. 54p.
Institut National de la Statistique (2014): Annuaire statistique du Niger 2010-2014. Recensement Général de la Population 2012. République du Niger, Niamey \{General Population census 2012.Republic of Niger, Niamey\}, 10 p.

Kim, J. - Ellis, C.D. (2009): Determining the effects of local development regulations on landscape structure: Comparison of The Woodlands and North Houston, TX. Landscape and Urban Planning 92: 293-303., DOI: 10.1016/j. landurbplan.2009.05.013

Landis, J.R.- Koch, G.G. (1977): The Measurement of Observer Agreement for Categorical Data. Biometrics 33(1): 159-174., DOI: $10.2307 / 2529310$

Lawali, S. - Yamba, B. (2012) : Insécurité foncière une menace pour l'agriculture familiale dans la région de Maradi. \{Land insecurity: a threat for family agriculture in the area of Maradi\}. Journal des Sciences de l'Environnement, 1 (1) : 35-42.

Leroux, L. (2012) : Analyse diachronique de la dynamique paysagère sur le bassin supérieur de l'Ouémé (Bénin) à partir de l'imagerie Landsat et MODIS : Cas d'étude du communal de Djougou. \{Diachronic analysis of landscape dynamics on the upstream of Ouémé valley (Bénin) from Landsat and MODIS imageries: Case of Djougou commune\}. Hydrosciences Montpellier, ANR ESCAPE, 62 p.

Mahamane, A. - Saadou, M. - Bakasso, Y. - Issaka, A. - Ichaou .A. and Karim S. (2007) : Analyse diachronique de l'occupation des terres et caractéristiques de la végétation dans la commune de Gabi région de Maradi (Niger). $\{$ Diachronic analysis of the landuse and vegetation characteristic in the commune of Gabi, region of Maradi (Niger)\}, Sécheresse 18 (4): 296-304., DOI: 10.1684/sec.2007.0105

Marthews, T.R. - Jones, R.G. - Dadson, S.J. - Otto, F.E.L. - Mitchell, D. - Guillod, B.P. - Allen, M.R. (2019): The Impact of Human-Induced Climate Change on Regional Drought in the Horn of Africa. Journal of Geophysical Research: Atmospheres 124: 4549-4566., DOI: 10.1029/2018JD030085

McGarigal, K. (2015): Fragstat help. https://www. umass.edu/landeco/research/fragstats/ documents/fragstats.help.4.2.pdf, 16.07.2016.

Mertz, 0. - Mbow, C. - Reenberg, A. - Genesio, L. - Lambin, E.F. - D’haen, S. -Zorom, M. Rasmussen, K. -Diallo, D. - Barbier, B. -Moussa, I.B. - Diouf, A. - Nielsen, J. Ø. -Sandholt, I. (2011): Adaptation strategies and climate vulnerability in the Sudano-Sahelian region of 
West Africa. Atmospheric Science Letters 12 (1): 104-108., DOI: 10.1002/asl.314

Rinaudo, T. (2010): Une brève histoire de la régénération naturelle assistée. Note technique \{A brief story of assisted natural regeneration. Technical note\}, echo@echonet.org, 27 p.

Sadda, A. S. - Diouf, A. - Lawali, S. - Ouedrago, M. Bogaert, J. - Mahamane, A. (2016): Pression anthropique et dynamique paysagère en zone rurale semi-aride: cas de la commune de Tibiri, région de Maradi (Niger). \{Anthropic pressure and landscape dynamics in semi-arid rural areas: the case of Tibiri commune, Maradi (Niger)\}. Tropicultura 34 (2): 127-139., ISSN: 0771-3312

Sarr, B. (2012): Present and future climate change in the semi-arid region of West Africa: a crucial input for practical adaptation in agriculture. Atmospheric Science Letters 13(2):108-112., DOI: $10.1002 /$ asl.368

Schlaepfer, R. (2002) : Analyse de la dynamique du paysage. \{Analysis of landscape dynamics\}. Fiche d'enseignement 4.2, Laboratoire de Gestion des Ecosystèmes, Ecole Polytechnique de Lausanne, Suisse. 10p.

Schowengerdt, R.A. (2007): Remote sensing models and methods for image processing. 3rd Edition, Elsevier/Academic Press, Oxford.
Story, M. - Congalton, R.G. (1986): Accuracy Assessment: A User's Perspective. 3. Photogrammetric, Engineering and Remote Sensing 52 (3): 397-399.

Sultan, B. - Janicot, S. (2004): La variabilité climatique en Afrique de l'Ouest aux échelles saisonnièreintra-saisonnière: mise en place de la mousson et variabilité intra-saisonnière de la convection $\{$ climatic variability in West Africa at seasonal and intra-seasonal scales: installation of monsoon and intra-seasonal variability of the convection\}, Sécheresse 15 (4): 321-330. ISSN: 1147-7806

World Bank (2007): World development Report, 2008: Agriculture for development Washington DC.

World Bank (2015): Estimations du personnel de la Banque Mondiale utilisant les perspectives des Nations Unies de l'urbanisation de la population. \{Estimates of the World Bank staff using the perspectives of the United nations for population urbanization\}, https//donnees. banquemondial.org/indicateur, 20.01.2017.

Zhang, J. (2003): Study on change detection framework of land use and landcover by remote sensing. China Land Science 17(4), pp. 31-36 